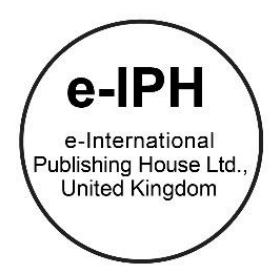

\title{
Sticking to the Old Ways in the Plea-Bargaining Process: Some evidence from Malaysia
}

\author{
Zaiton Hamin ${ }^{1}$, Mohd Bahrin Othman ${ }^{1,2}$, Ahmad Ridhwan Abd Rani ${ }^{1}$ \\ 1 Faculty of Law, ${ }^{2}$ Student Affairs and Alumni Division, \\ Universiti Teknologi MARA, Shah Alam, Selangor, Malaysia \\ zaiton303@salam.uitm.edu.my, mohdb916@salam.uitm.edu.my, ridhwanrani@icloud.com \\ Tel of 1 st Author: 019-3798359
}

\begin{abstract}
In Malaysia, the plea-bargaining process was formalized in 2010 with the amendment to the Criminal Procedure Code 1976, which was intended to reduce the number of criminal cases that could be resolved at the pre-trial stage. However, the law in action does not appear to be in line with the law in the statute book. Hence, this paper aims at examining the reality of the plea-bargaining process and the extent of the applications in Malaysia. This paper adopts a qualitative methodology, of which the primary data is obtained from semi-structured while the secondary data obtained from librarybased sources.
\end{abstract}

Keywords: Plea-Bargaining Process; Criminal Procedure; Prosecutor; Defence Counsel

eISSN: 2398-4287 @ 2020. The Authors. Published for AMER ABRA cE-Bs by e-International Publishing House, Ltd., UK. This is an open access article under the CC BYNC-ND license (http://creativecommons. org/licenses/by-nc-nd/4.0). Peer-review under responsibility of AMER (Association of Malaysian Environment-Behaviour Researchers), ABRA (Association of Behavioural Researchers on Asians) and cE-Bs (Centre for Environment-Behaviour Studies), Faculty of Architecture, Planning \& Surveying, Universiti Teknologi MARA, Malaysia.

DOI: https://doi.org/10.21834/ebpj.v5iSI1.2324

\subsection{Introduction}

The plea-bargaining process which allows the prosecutor to engage with the accused person and the defence counsel in an informal discussion is aimed at resolving a criminal case without involving a full trial and thus saving their time and expenses (Bibas, 2016). The outcome of such a discussion, which requires the accused person to self-incriminate himself, would result in either a charge or sentence reduction (Wan, 2007). The conversational nature of such a process empowers the parties to navigate their way through the criminal justice system (Condlin, 2011). The said process has been considered not only as a fast and swift justice process but also as a progressive model for disposing of criminal cases.

Within the global context, the plea-bargaining process is a success in several jurisdictions. For example, in the United States, such a process is considered as a preferred alternative where 90 to 95 per cent of cases have been resolved through such a system (Devers, 2011). In Singapore, the process has played a crucial role in weeding out and determining simple criminal cases from the full trial, which proves to be cost-effective for the parties (Koman, 2016). In Malaysia, in response to reported abuse of power by the prosecutors, some commentators had called for a formal introduction of the plea-bargaining process, (Srimurugan, 2010; Akram 2005). The law on the formal plea-bargaining process finally came to light in 2010 when the CPC 1976 was amended to add two new provisions - section $172 \mathrm{C}$ and 172D. However, the implementation of the law as practised by the prosecutors and defence counsels or what is termed as 'the law in action" and the procedures laid down in the CPC 1976 or "the law in the statute book" may not be at congruence with one another. Thus, this paper attempts to examine the reality of the plea-bargaining process and the extent to which the procedural practice by the relevant actors embraces the spirit of the new law.

This article is divided into five parts. The first part of the article examines the literature on the plea-bargaining process. The second part reviews the procedural rules of the plea-bargaining process as provided by the CPC 1976. The third part explains the methodology 
of this research. The fourth part which is the crux of this article highlights the findings and discussion, focusing on the interaction of the parties to the legal changes in plea-bargaining and the justification for their practices and attitudes. The final part concludes the article by suggesting that, despite the introduction of the new formal plea-bargaining process, the criminal justice actors are rather keen to stick to the traditional way of bargaining due to organizational and technical rationales.

\subsection{Literature Review on Plea-Bargaining Process}

The plea-bargaining process is considered as an incentive for the defendant, which also enables the prosecutors to obtain guilty pleas without having to go to full trials. Cohen and Doob (1990) explain that the process takes the form of an agreement by the accused to plead guilty, to several if not all charges, in return for the prosecutor's agreement to take or refrain from taking a particular course of action. Similarly, Akram (2005) contends that the nature of the plea-bargaining process consists of reciprocal agreement and arrangement between two major players in the criminal justice system - the prosecutor and the accused person. Akram (2005) divides plea-bargaining into two types, namely the implicit type or explicit type. While the former is when the accused pleads guilty as he feels that this is the route to a lesser sentence, the latter type occurs when the accused only agrees to plead guilty after he has an assurance that he will receive some concessions in his case.

An essential feature of the plea-bargaining process is its voluntariness nature as such a process would require the agreement and mutual understanding between the prosecutors and the defendants (Parker, 1972). From the historical perspective, Varga (1976) contends that the essential elements of voluntariness of the accused in the plea-bargaining process may be traced back to an English treatise devoted exclusively to criminal law, which is the Staundforde's Pleas of the Crown. In 1560, the said treaties declared that a guilty plea was arising from "fear, menace, or duress" should not be recorded. In determining such voluntariness, the said treaties stated that the court should properly examine the accused of his competency in making a plea bargain application.

The extant literature suggests that the organizational perspective of plea-bargaining relates to the perception that the court is one big organization that holds the process of justice as its main subject-matter and interest. This assumption relies on the notion surrounding plea-bargaining as an interaction of actors within the court setting. Feeley (1973) suggests that the implication arising from the interaction between the actors in the subsequent organizational impact of the plea-bargaining process. Here, the judge represents the judiciary while the prosecutor represents the Attorney-General Chamber. Each organization has different goals with different ways of making their decisions. As a significant actor in the plea-bargaining process, the prosecutors would usually shape the direction of such a process. Burstein (1980) suggests that the prosecutor holds more control over the management of the court process at the pre-trial stage. The prosecutors possess extensive discretionary powers over the direction of the case during the preliminary stage of a criminal proceeding. Such discretion would give them the upper hand in the plea-bargaining process. Nevertheless, being part of the Attorney-General Chambers, the prosecutors are bound by specific organizational constraints such as meeting certain datelines and hierarchical politics.

Feeley (1982) argues that the prosecutors are generally expected to achieve some performance index, such as reaching a certain number of convictions or maintaining a certain standard of the sentence. Feeley further elaborates that the prosecutor's self-interest has been factored to impact the plea-bargaining process. The political urge to maintain a high rate of conviction, which is desired by the top management in the prosecution office, would have an impact on the decision-making process of the prosecutor during the pleabargaining process (Padgett, 1985). Due to scarcity of literature that analyzes the effect of organizational constraint on the implementation of the plea-bargaining process in Malaysia, this paper aim at filling the gap by providing relevant data on the effects of organizational constraint on the plea-bargaining process.

\subsection{Procedural Rules Regulating Plea-Bargaining Process in Malaysia}

The plea-bargaining process was formally introduced in 2010 and came into force in 2012. Before the amendment and for a long time, the practices adopted by the prosecutors and the defence counsels were without any legal recognition. Despite the advantages that such practices could offer, these practices had exposed the accused to several malpractices by the prosecutor. For instance, Akram (2005) observes that such malpractice is a direct consequence of the lacuna in the Malaysian legal provision. Among recorded abuse of power by the prosecutor in the plea-bargaining process includes not honouring the agreement to charge the accused leniently after the accused had pleaded guilty. Subsequently, the amendment was made to the CPC 1976 to recognize the practice within the criminal justice system in Malaysia. The government spearheaded such amendment as a double edge strategy, which was to protect the interest of the accused person as well as to reduce the workload of the courts and the number of the backlog of cases (Patail, 2012).

Section 172C and 172D of the CPC 1976 provides for the new procedures for the plea-bargaining process. Section 172C (1) provides that the application for plea-bargain shall come from the accused person to the court directly. Such an application shall be made by filing in Form 28A of the Second Schedule, which contains the information on the charges of the accused person, the declaration that such application is made voluntarily, and the type of bargaining that the accused intends to engage, either charge bargaining or sentence bargaining. After the application has been made, section 172C (3) provides that the court shall notify the prosecutor and date will be given for a hearing of such application. The court shall later, examine the voluntariness of the accused person in-camera before making any arrangement for the disposal of the case as provided by section $172 \mathrm{C}$ (4). When the court is satisfied that the application is voluntary, the parties may then prepare and sign a mutually satisfactory disposition of the case agreement.

Section 172D provides the next procedure to guide the disposition of the case according to the application for the plea-bargaining process through Form 28A. Section 172D (1) states that the court shall dispose of the case in three manners. Firstly, the court shall make an order according to section 426 of the CPC 1976 for payment of the cost of prosecution and compensation. Secondly, in the 
application for plea-bargaining of the charge, the court shall find the accused person guilty and sentence the accused accordingly. Thirdly, in determining the application for plea-bargaining for a sentence, the court shall find the accused person guilty and deal with the accused under section 293 for the first offender and section 294 to execute the condition of bonds. Also, the court may sentence the accused to not more than half of the maximum punishment. However, section 172D (3) is an exception to the earlier provision on the reduction of the sentence through plea-bargaining. This section states that the reduction of the sentence which is not more than half does not apply to the accused that has been charged under five situations. These situations include the following:1) the accused is being charged with an offence where the punishment is fine only, 2) the offence involve the punishment for imprisonment for natural life, 3) any sexual-related offence, 4) any offence committed against a child who is below the age of twelve, or 5) any other offence specified by the Public Prosecutor in the Gazette.

\subsection{Methodology}

This study focuses on the reality of the implementation of the plea-bargaining process at the pre-trial stage in Malaysia. This research employs a qualitative research methodology that aims at providing a deeper understanding of the process as well as gaining a more extensive and comprehensive overview of the subject matter under study (Silverman, 2005). For this paper, the findings of this research are based on the data collection of both the primary and the secondary data which is divided into two phases. The first phase of the data collection stage is the library-based research or the literature review stage in which the relevant literature on the concepts of pleabargaining and its legal and procedural positions are reviewed (Bell, 1987). The secondary data collected and reviewed at this stage include primary sources such as the CPC 1976 and the secondary sources involving textbooks, academic journal articles, government reports, newspaper articles, online databases, and online sources.

The second phase of the data collection is the fieldwork, in which the primary data is generated by adopting face-to-face semistructured interviews with the respondents who are the stakeholders in the plea-bargaining process (Gill, Stuart, \& Anor, 2008). Bertaux (1981), Guest, Bunce, and Johnson (2006) suggest that 15 respondents are the minimum sample size for qualitative research. Thus, fifteen to twenty respondents are selected comprising of deputy public prosecutors, defence counsels, judges at the Sessions Court and Magistrates, and the accused person. The selection of the respondents is based on purposive sampling which relies on their respective roles within the plea-bargaining process (Crouch and McKenzie, 2006). The said primary data is triangulated with the semi-structured interview (Seidman, 2006) data obtained from two members of the Criminal Law Committee of the Malaysian Bar Council.

The third phase of the research is a qualitative data analysis, which is conducted through thematic and content analyses (Siedman, 2006), through which the interview transcripts from the semi-structured interviews and the observations made during the said interviews are analyzed (Blandford, 2013). The process consists of creating codes and categories, considering the themes, and then creating hypotheses about the respondents' experiences, along with the literature review. All the said interviews are digitally recorded, and their contents have been transcribed and analyzed using the AtlasTi qualitative research software (Silver \& Lewin, 2014).

\subsection{Result}

\subsection{Awareness of the Legal Changes}

The findings indicate that the legal changes in the plea-bargaining process are well-known and well-received by all actors in the criminal justice system. Such awareness of the new procedures leads to the perception that the existing process is no longer a secret and the parties may openly approach the other side to resolve their cases. One respondent remarks that:

We all know that plea bargaining is much easier and open these days... it's not a secret anymore...

The findings show that the CPC 1976 has shed light on a better-guided discussion, which may promote transparency between the parties. The findings suggest that the prosecutor benefits from the new provision and that the openness of the new plea-bargaining process has dispelled the cloak of secrecy of the process. One prosecutor from Putrajaya suggests that:

Before the amendment of the CPC on the formal plea-bargaining, we were quite scared to receive a visit from any defence counsel... as the meeting might raise some questions about professional misconduct and may compromise our case. But not anymore, we can now arrange the meeting openly.

The study reveals that the defence counsels are more assured of their agreement with the prosecutors after the legal changes came into effect. Such a situation is because the formal procedures on plea-bargaining require that the application to bargain must be made by issuing Form $28 \mathrm{~A}$ to the court. The form shall include the details of agreed facts as well as the agreed charges. Once the said document has been appropriately tendered to the court, the counsels would be assured that the prosecutor would honour the agreement made between them. One defence counsel who had vast experience in criminal cases has shared his experiences on the formal pleabargaining process as tying a knot with the system and remarks that:

One of the advantages of the formal plea-bargaining is that the process is now documented. You write and submit the document, and then you are provided with the evidence. The judge cannot run away from it, the prosecutor cannot run away from it, and you also cannot run away from it.

\subsection{Lack of Application of the New Law}

An interesting finding of this study shows that the formal plea-bargaining process is not widely used by the prosecutors and the defence counsels in their dealing at the pre-trial stage. Since its introduction in the CPC seven years ago, Form 28A is under-utilized and is left to collect some dust on the legal shelves. One Respondent states that: 
The plea-bargaining process, as provided by section $172 \mathrm{C}$ and section $172 \mathrm{D}$ of the CPC is taken for granted. From my own experience, almost 90 pecent of lawyers do not use the new formal plea-bargaining process.

\subsection{Justification for Lack of Application: Organisational Constraint}

The findings indicate that several factors may contribute to the unwillingness of the criminal justice actors to apply the new procedural law. One prosecutor from Selangor explains that the extent of the application of formal plea-bargaining process as beyond belief and states that:

...I can't really believe it ... lawyers still prefer and practice the old informal way.

The study finds that organizational constraint in the form of following superior orders results in the lack of adherence to the new procedural rule in the CPC. It is found that in the plea-bargaining process, the deputy public prosecutors (DPP) may not have the full discretion to decide whether or not to approve the agreed reduction of charges or sentences. Such a situation is because they have to observe the specific hierarchical chain of command and would have to follow the decision of their superiors. One respondent who explains the limited discretion of the DPP states that:

The prosecutors may look powerful with the CPC to help them. But the reality is that they are constrained by their superiors and prosecute their cases with one hand being tied.

Another respondent who is a defence counsel also believed that the DPP's power is not as broad as envisaged by the CPC and they must toe the line of their superiors. He states that:

The prosecutors might want to plea-bargain and reduce their workloads, especially in simple criminal cases. But they must obey their bosses' orders. If they continue with the plea-bargaining when their bosses don't allow them to proceed, they'd be in trouble.

\subsection{Justification for Lack of Application: Technical Delay}

The findings also revealed that the technical delay when the new procedures in the CPC 1976 are followed has led to an unfavourable stance towards the new law. Some of the respondents, in particular, the defence counsels, do not think that the formal plea-bargaining process is a faster alternative to the disposal of criminal cases. They consider the application via Form 28A is a dead end because the formal plea-bargaining process takes a longer time to process. One respondent lament that:

Form $28 \mathrm{~A}$ is a good initiative to improve the plea-bargaining process. But the plea bargain may take a longer period before it could come to the disposition of the case.

Another respondent explains the rationale for the delay and remarks that:

The DPPs would have to get instructions and certification from their headquarters or bosses whether to proceed and agree to dispose of the case or not. Such certification may take days if not weeks...

The findings indicate that as a result of this procedural delay, some of the respondents prefer to plea-bargain with the prosecutors in an old informal way, which is somewhat similar to the position before the amendment. A respondent argues that:

$\ldots$ if the plea-bargaining process is conducted informally, only mutual disposition agreement between the prosecutor, the defence counsel and the judges is required. Some cases can be disposed of in one day without using the Form...

\subsection{Discussion}

The findings indicate that CPC 1976 brings new procedural changes to the implementation of the plea-bargaining process. The findings on the perception, awareness, and acceptance of the said legal changes reflect Akram's view (2005) that highlights the legal lacuna exists and is real. The findings also suggest that despite the awareness of the new manner of conducting the plea-bargaining process, there is an unwillingness on the part of the parties to apply the new procedures. Such lack of application of the law is mainly due to the organizational hindrance and confirms the literature that the prosecutor's discretion to decide and determine the disposition of a case in the plea-bargaining process is constrained and limited to the organizational goals (Feeley, 1980; Padgett, 1985).

The findings indicate that contrary to section 172D of the CPC 1976 which states that the prosecutor has the power to decide on the mutual disposition of cases and steers the cases where he sees fit, the prosecutors are left with little discretion as they are bound to follow their superior's orders. The findings further reveal that the implementation of the plea-bargaining process is contradictory to the spirit of the amendment to the Criminal Procedure Code. The opening speech by the then-Attorney General, Tan Sri Abdul Ghani Patail emphasizes that the introduction of a formal plea-bargaining process is to speed up the process of criminal trial and to weed out simple criminal cases that can quickly be resolved at the pre-trial stage (Ghani Patail, 2013). The implementation of the new procedures has failed to reduce the time spent in resolving the plea-bargaining process.

\subsection{Conclusion}

It is undeniable that the introduction of section $172 \mathrm{C}$ and section $172 \mathrm{D}$ of the CPC 1976 is envisaged to improve the plea-bargaining process in Malaysia. Nevertheless, the preliminary findings of this study indicate that the reality of the implementation of such a process or 'the law in action' is not in accordance with the CPC provisions or 'the law in the statute book.' Such a disparity is evident from the findings that the Form 28A is under-utilized and the majority of the respondents prefer sticking to the old ways of bargaining without any written agreement or form. The primary justifications for this unwillingness to change to the new procedures are the organizational constraints and the technical delays resulting from the use of the said Form. The findings suggest that despite the legal changes that are envisaged to enhance and formalize the plea-bargaining process as well as to safeguard the interests of the accused person from 
the arbitrary discretion of the prosecutors, sticking to the old ways remain the order of the day. If the status quo is unchanged, it is likely that Form $28 \mathrm{~A}$ may be collecting considerable dust on the legal shelf in the years to come.

\section{Acknowledgments}

This work is supported by research grant 600-IRMI/Dana KCM 5/3/Lestari (115/2017) by the Research Management Centre, Universiti Teknologi MARA, Shah Alam, Selangor.

\section{References}

Anderson, R. (1998). Intuitive Inquiry: A Transpersonal Approach. In W. Braud \& R. Anderson, Transpersonal Research Methods for the Social Sciences: Honoring Human Experience (pp. 69-94). Thousand Oaks, CA: Sage Publication

Bell, J. (1987). Doing Your Research Project - A Guide for First-Time Researchers in Education and Social Science. Philadelphia: Open University Press.

Bibas, S. (2016), Designing Plea Bargaining from the Ground Up: Accuracy and Fairness Without Trials as Backstops. Faculty Scholarship. Paper 1644.

Bertaux, D. (1981). From the Life-History Approach To The Transformation Of Sociological Practice. Biography And Society: The Life History Approach In The Social Sciences. 29-45. London: Sage.

Blandford, Ann (2013): Semi-structured qualitative studies. In: Soegaard, Mads and Dam, Rikke Friis (eds.). "The Encyclopedia of Human-Computer Interaction, 2nd Ed." Aarhus, Denmark: The Interaction Design Foundation. Available online at http://www.interactiondesign.org/encyclopedia/semi-structured_qualitative_studies.html

Burstein, C. (1980). Criminal Case Processing From An Organizational Perspective: Current Research Trends. The Justice System Journal, $258-273$.

Cohen, S. A., \& Doob, A. N. (1989). Public Attitudes to Plea Bargaining. Crim. LQ, 32, 85.

Condlin, R.J. (2011). Bargaining without Law. N. Y. L. Sch. L. Rev. 281

Crouch, M., McKenzie, H. (2006) The Logic of Small Samples in Interview-based Qualitative Research. Social Science Information. Vol. 45 No. 4 pp: $483-499$.

Devers, L. (2011). Plea and charge bargaining. Research summary. Available online at https://www.bja.gov/publications/pleabargainingresearchsummary.pdf Feeley, M. M. (1973). Two Models Of The Criminal Justice System: An Organizational Perspective. Law \& Society Review, 7(3), 407-425.

Gill, P., Stewart, K., Treasure, E., \& Chadwick, B. (2008). Methods Of Data Collection In Qualitative Research: Interviews And Focus Groups. British Dental Journal, 204(6), 291-295.

Guest, G., Bunce, A., Johnson, L. (2006) How Many Interviews Are Enough? An Experiment with Data Saturation and Variability. Field Methods. Vol. 18 No. 1 pp: $59-82$ Koman, R. N. (2016). Balancing the Force in Criminal Mediation. Beijing Law Review, 7(03),171.

Mohammad Akram, (2005), Plea Bargaining: The Underlying Rationale and The Malaysian Experience, 5 MLJ xlii

Heumann, M. (1981). Plea Bargaining: The Experiences Of Prosecutors, Judges, And Defense Attorneys. University of Chicago Press.

Padgett, J. F. (1985). The Emergent Organization Of Plea Bargaining. American Journal Of Sociology, 90(4), 753-800.

Parker, J. F. (1972). Plea Bargaining. Am. J. Crim. L., 1, 187.

Seidman, I. (2006). Interviewing as Qualitative Research. New York: Teachers College Press.

Silverman, D. (2005, September). Instances or sequences? Improving the state of the art of qualitative research. In Forum Qualitative Sozialforschung/Forum: Qualitative Social Research (Vol. 6, No. 3).

Silverman, D. (2013). Doing Qualitative Research. Los Angeles: SAGE.

Silver, C., \& Lewins, A. (2014). Using Software In Qualitative Research: A Step-By-Step Guide. Sage.

Singh, B. S. Singh. (2015) Criminal Litigation Process. 3rd Edition, Sweet \& Maxwell. Subang Jaya.

Speech by Tans Sri Abdul Ghani Patail, Attorney General of Malaysia, At the Opening of the Legal year 2012, MLJ (2012) 1 cxiii.

Srimurugan (2010). Importing the Concept Of Plea Bargaining Into The Criminal Procedure Code In Malaysia. CLJ. 5. Xxix

Varga, J. G. (1976). Plea Bargaining: An Overview. Glendale L. Rev., 1, 235.

Wan, T. (2007). Unnecessary Evil of Plea Bargaining: An Unconstitutional Conditions Problem and Not-So-Least Restrictive Alternative, The. S. Cal. Rev. L. \& Soc. Just., 17,33 